\title{
Rupture of a giant abdominal aortic aneurysm
}

\author{
Dragan Piljićc ${ }^{*}$, Mustafa Tabaković ${ }^{1}$, Almir Kusturica', Alen Hajdarević ${ }^{1}$, Tomislav Klokočovnik² \\ From 23rd World Congress of the World Society of Cardio-Thoracic Surgeons \\ Split, Croatia. 12-15 September 2013
}

We admitted a 76-year old male person with a ruptured abdominal aortic aneurysm. He was immediately brought to the emergency room (ER). The blood pressure was $80 / 40 \mathrm{mmHg}$, HTC less than 0.17 . We decided to perform an emergent $\mathrm{CT}$ angiography wich verified referral diagnosis. The ruptured AAA was $12 \mathrm{~cm}$ in diameter. An emergent life saving operation had to be done so the patient was brought to the operation theatre (OT). The approach to the abdomen was a classic median laparotomy. After we had opened the abdomen, we found a huge retroperitoneal haematoma that pushed beside the intra-abdominal organs rising almost to the edge of the rectal fascia. The blood pressure suddenly dropped down to $45 / 25 \mathrm{~mm} \mathrm{Hg}$ for the next several minutes. A continuous infusion of norepinephrine was administered $(60 \mathrm{mcg} / \mathrm{min})$ and we also administered several doses of pure adrenalin $(3 \mathrm{mg})$ and pure norepinephrine $(1 \mathrm{mg})$. We pulled out the intestines from the abdominal cavity and clamped the aorta just under the renal arteries. The blood pressure immediately rose to $80 \mathrm{~mm} \mathrm{Hg}$. Both common iliac arteries were clamped, too. During the surgery the patient was anuric. Autologous blood transfusion helped by cell saver was administered and additionally he got several doses of blood, blood derivates (fresh frozen plasma, cryoprecipitate, platelets) and other intravenous solutions at the amount of approximately eight litres. We replaced the ruptured AAA using $20 \mathrm{~mm}$ PTFE vascular graft. After surgery the patient was transferred to the intensive care unit (ICU) where the blood pressure rose and diuresis was established.

First postoperative day the patient was woken up without neurological deficits. Second postoperative day the patient was able to expel the stool and he was transferred to the department of cardiovascular surgery.

\footnotetext{
* Correspondence: dragan.piljic@dr.com

'Department of Cardiovascular Surgery, University Clinical Center Tuzla, Tuzla, Bosnia and Herzegovina

Full list of author information is available at the end of the article
}

Tenth day after surgery he was discharged home. Six weeks after surgery we performed a control CT angiography that showed normal founding on the abdominal iliac and leg vessels.

\section{Authors' details}

${ }^{1}$ Department of Cardiovascular Surgery, University Clinical Center Tuzla, Tuzla, Bosnia and Herzegovina. ${ }^{2}$ Department of Cardiovascular Surgery, Ljubljana University Medical Centre, Llubjana, Slovenia.

Published: 11 September 2013

doi:10.1186/1749-8090-8-S1-P11

Cite this article as: Piljić et al:: Rupture of a giant abdominal aortic aneurysm. Journal of Cardiothoracic Surgery 2013 8(Suppl 1):P11.

\section{Submit your next manuscript to BioMed Central and take full advantage of:}

- Convenient online submission

- Thorough peer review

- No space constraints or color figure charges

- Immediate publication on acceptance

- Inclusion in PubMed, CAS, Scopus and Google Scholar

- Research which is freely available for redistribution

Submit your manuscript at www.biomedcentral.com/submit

\section{() Biomed Central}

C Biomed Central

C 2013 Piljić et al; licensee BioMed Central Ltd. This is an Open Access article distributed under the terms of the Creative Commons Attribution License (http://creativecommons.org/licenses/by/2.0), which permits unrestricted use, distribution, and reproduction in any medium, provided the original work is properly cited. 